\title{
USE OF VAGRANCY-TYPE LAWS FOR ARREST AND DETENTION OF SUSPICIOUS PERSONS:
}

INDIVIDUAL liberty and the competing demands of crime prevention in the modern, highly-mobile community are often hard to reconcile. Faced with increasing crime as urban development becomes more complex, ${ }^{1}$ municipalities often find law enforcement seriously hampered by traditional restrictions on the power to arrest without a warrant. ${ }^{2}$ As a consequence, cities and states have increasingly utilized vagrancy ${ }^{3}$ and suspicious per-

they depend upon the radio for support at election time. While there have been no recent pronouncements on the matter, several attempts to pass legislation forbidding the FCC to make any rule, regulation or order prohibiting cross-channel ownership have died in committee. See, e.g., Hearings Bcfore Committec on Interstate and Foreign Commerce on $S$. $1333 \S 25,80$ th Cong., 1st Sess. 12, 69 (1947).

$\dagger$ Member second-year class, Yale Law School. 1949).

* City of Portland v. Goodwin, 210 P.2d 577, rehcaring denicd, 210 P.2d 577, 586 (Ore.

1. See United States Dep't of Justice, Uniforar Criare Reports, Vol. XVI, pp. 73, $78-81$ and passim (1946).

2. At common law, a peace officer may, in general, arrest without a warrant and without judicial authorization when (a) a felony or a misdemeanor amounting to a breach of the peace is committed or attempted in his presence, (b) iwhen he has reasonable grounds to believe that the arrestee has committed a felony, or (c) the arrestee is an escaped prisoner. Clark, Handzook of Crammal. Procedure 45 (2d ed. 1918).

In most states, the common law rules have been incorporated into statutes-usually with some extension of power. These statutes often authorize arrest without a varrant for all offenses committed in the presence of the arresting officer, including misdemeanors that do not amount to breaches of the peace. CIARK, op. cit. supro at 50. In addition, many statutes authorize an officer to arrest a person when he has been notified that another peace officer of the state holds a duly issued warrant for the arrest of such person. See e.g., ORE. CoMrp. LAws ANN. \$26-1532 (1940).

Under both the common law and the statutory law of arrest, the police must establish reasonable grounds for obtaining a warrant or for arresting without a warrant. Mfodern transportation being what it is, delays in establishing reasonable grounds often permit the criminal to scram from the jurisdiction.

The dragnet or "round-up," one of the most widely used police methods, is illegal under the law of arrest in most states, unless vagrancy-type statutes are used to justify the arrests. See note 5 infra.

3. Vagrancy laws, which now exist in most jurisdictions in the Anglo-American countries, first appeared in crude form in Ireland in the fifth century and in England in the seventh century. Rrbton-TurNer, A History of Vagrants and Vacrancx 5, 374-5 (1887). For general discussion of present vagrancy laws in the United States, see Lisle, Vagrancy Law; Its Faults and Their Rennedy, 5 J. Crrar. L. \& Crrurrionory 493 (1914) ; Grossman, Who Is a V'agrant in California?, 23 Calm. L. REv. 506 (1935). "Besides penalizing professional gamblers, common drunkards, beggars, and swindlers, the majority contain more general provisions, defining as vagrants all "idle, lewd and dissolute persons,' 'associates of known thieves,' or persons 'without visible means of support." N.Y. Law Revis. Comin's Rep. 593, 594 (1935) quoted in Dession, Crasuanl Law, Administration and Public Order 153 (1948). The statutes are collected in MIreuiga:: State Library, Laws of the Various States Remating to Vagraxcy (1916). 
sons ${ }^{4}$ statutes, which permit wider police discretion in arrest of persons suspected of having committed or of intending to commit a crime. ${ }^{6}$ Appearing in a great variety of forms and language, these statutes frequently make it an offense for any person to wander about without having "lawful business" or without being able to give a "good account of himself."

Statutes of this kind almost always offend traditional standards of criminal procedure. In fact, if not in legal theory, they burden defendants with a presumption of criminality; ${ }^{6}$ and of ten they are so broadly phrased as to

Some of the statutory definitions of vagrancy resemble, to some extent, the Portland, Ore., curfew ordinance discussed in this note. For example, under Ordinance $27, \S 2$, of the City of Juneau, Alaska, the following are vagrants :

"All persons having no known occupation or business, who shall be found wandering about the streets of the city of Juneau after the hour of eleven o'clock at night. . . ." Sec Guidoni v. Wheeler, 230 Fed. 93 (9th Cir. 1916) (Juneau ordinance upheld). See also IDAHo CODE $\$ 18-7101$ (1948): "[E]very person who roams about from place to place without any lawful business; every idle and dissolute person, or associate of known thieves, who wanders about the streets at late or unusual hours of the night . . . [is a vagrant.]" See State v. Preston, 4 Idaho 215, 38 Pac. 694 (1894) (upholding ordinance phrased like present statute).

4. Suspicious persons laws take various forms and names. See, for example, Trax. Code Crim. Proc. art. 214 (Vernon, 1925): "The municipal authorities of towns and citics may establish rules authorizing the arrest, without a warrant, of persons found in suspicious places, and under circumstances which reasonably show that such persons have been guilty of some felony or breach of the peace, or threaten, or are about to commit some offense against the laws." See also, Disorderly Persons Act, N.J. Stat. Ann. $\S 2: 202-16$ (1939): "Any person who shall be apprehended . . . who cannot give a good account of himself, or who is engaged in an illegal occupation and who is in this state for an unlawful purpose, shall be adjudged a disorderly person." Held constitutional in McNeilly v. State, 119 N.J.L. 237, 195 Atl. 725 (1937). And see Mass. Gen. Laws c. 41 \& 98 (1932) (authorizing arrest of suspicious persons "who do not give a satisfactory account of themselves").

5. Police undoubtedly find these statutes of considerable aid in crime prevention. See e.g., State v. Grenz, 26 Wash. 2d 764, 175 P.2d 633 (1946) (chicken thief arrested under vagrancy law as he was about to enter chickenyard) ; McNeilly v. State, 119 N.J.L. 237, 195 Atl. 725 (Sup. Ct. 1937) (thief apprehended under Disorderly Persons Act while looking for a suitable store window to break); State v. Hall, 52 A.2d 845 (N.J. Ct. of Special Sess., Essex County 1947) (prostitute arrested under Disorderly Persons Act while accompanying a man to an appropriate place in which to ply her trade).

These laws are used as legal justification for the dragnet or "round-up." Either periodically, or when a serious felony has been committed, the police arrest all known or suspected criminals in the vicinity to be questioned, fingerprinted and shown to witnesses. Frequently, the police follow the custom of repeatedly jailing on vagrancy charges known or suspected criminals against whom no serious crime can be proven in order to keep them out of circulation and pursuade them to leave town. Eimbeck, Somc Reccut Methods of Harassing the Habitual Criminal, 16 ST. Lours L. REv. 148, 151-S (1931); Kooken, Ethics in Police Service, 38 J. Crim. L. \& Crmmology 61, 179 (1947). Such use of these laws is often admitted publicly. Hall, The Lawe of Arrest in Relation to Contemporary Social Problems, 3 U. of Car. L. Rev. 345, 369 n.90 (1936). And sec Hopkins, OUR Lawless Police 96 and passim (1931).

6. Under most of these laws, the prosecution need prove only that the defendant failed to meet his burden of proving that his purpose abroad was lawful-that he failed to give 
permit the police and trier of fact to determine the question of guilt according to their own moral and political standards. Nevertheless, when challenged on constitutional grounds, vagrancy and suspicious persons statutes have usually been upheld as a reasonable exercise of the police power. ${ }^{7}$ Sanctioned by historical usage ${ }^{8}$ and apparently recognized by modern courts as indispensable instruments of present day law enforcement, such statutes run into trouble only when unduly vague ${ }^{9}$ or when couched in terms unfamiliar to precedent-minded courts. ${ }^{10}$

a "good" or "satisfactory" account of himself. For example, in a prosecution under the Disorderly Persons Act, N.J. STAт. ANN. \$2:202-16 (1939), the failure of the defendant to give a good account of himself is made prima facie evidence that he is in the state for an unlawful purpose. This provision was approved in State v. Hall, 52 A.2d 845 (N.J. Ct. of Special Sess., Essex County 1947), where the court said that the burden of proof remained on the State to establish defendant's guilt, and that his failure "to talk" was merely a rebuttable presumption against the defendant. And see Neal v. City of Dublin, $20 \mathrm{Ga}$. App. 263, 92 S.E. 1021 (1917) (upholding an ordinance which forbade "any woman of disreputable character to loiter about the streets or stores of the city ... who cannot prove that [she is] on unavoidable business."). Contra: People v. Licavoli, 264 Mich. 643, 250 N.W. 520 (1933) (disorderly persons law penalizing reputed criminals invalidated because it denied defendants the presumption of innocence).

7. See, e.g., MicNeilly v. State, 119 N.J.L. 237, 195 Atl. 725 (Sup. Ct. 1937) (Disorderly Persons Act) ; State v. Grenz, 26 Wash. 2d 764, 175 P. 2d 633 (1946) (vagrancy law) ; City of New Orleans v. Postek, 180 La. 1048, 158 So. 553 (1934) (vagrancy and suspicious persons ordinances) ; City of Columbus v. MicCrory, 49 N.E.2d 583 (Ohio Ct. of App., 2d Dist. 1942) (suspicious persons ordinance); In re Cutler, 1 Cal.App.2d 273, 36 P.2d 441 (4th Dist. 1934) (vagrancy law). But cf. Mfayor of Memphis v. WVinfield, 8 Humph. 707 (Tenn. 1848) (curfew ordinance held unconstitutional; but distinguishable because there were no exceptions for lawful purpose or urgent business).

8. See Ribton-Turner, op. cit. supra note 3, passin.

9. If a law "describes the act denominated as a crime in terms so general and indeterminate ... and of such a nature that honest and intelligent men are unable to determine what particular act is condemned by the state, the law is incapable of enforcement and will be held to be null and void." People v. Belcastro, 356 IIl. 144, 149, 190 N.E. 301, 304 (1934) (invalidating a vagrancy law).

Because of the vague language used, these laws have also been attaclied as punishing for unlawful intent alone, contrary to "the general rule of the common law ... that a mere intent to commit a crime, unaccompanied by any overt act was insufficient to constitute a crime" Minler, HandBook of CRDImal Law 95 (1934); Mfiles v. State, 58 Ala. 390 (1877) ; Ex parte Smith, 135 Mo. 223, 36 S.WW. 628 (1896) (invalidating ordinance penalizing consortion with reputed thieves).

If presence in the state or in a public place is the overt act, freedom of locomotion is infringed: "Personal liberty, which is guaranteed to every citizen under our constitution and laws, consists of the right of locomotion,- to go where one pleases, and when, and to do that which may lead to one's business or pleasure, only so far restrained as the rights of others may make it necessary for the welfare of all other citizens." Pinkerton v. Verberg, 78 Mich. 573, 584, 44 N.W. 579, 582 (1859), quoted in Territory of Hawaii v. Anduha, 31 Hawaii 459, 463 (1930), affd, 48 F.2d 171 (9th Cir. 1931) (invalidating a loitering ordinance).

10. Those laws which are phrased differently from the traditional definitions of "vagrancy" have had greater difficulty in surviving constitutional tests. The most vulnerable statutes are those which depend almost entirely on the evil reputations and asso- 
City of Portland v. Goodwin 11 illustrates the vigorous effort a court will sometimes make to preserve doubtful legislation of this kind. At stake in this case was an adult curfew ordinance ${ }^{12}$ making it unlawful to be on the street between 1:00 and 5:00 A.M. "without having and disclosing a lawful purpose." 13 The regulation was challenged as unconstitutional on its

ciations of the defendants to constitute the offense. Such laws are frequently held to be too vague- the courts usually implying that statutes of the usual type, whose broad phrases have acquired more definite content through years of judicial construction, would be upheld. Stoutenburgh v. Frazier, 16 App. D.C. 229 (1900) (statute penalizing "all suspicious persons" invalidated for not adequately defining a crime and thus authorizing unreasonable seizure [U.S. Const. AmEND. IV] and cruel and unusual punishment (U.S. Const. Amend. VIII)) ; People v. Licavoli, 264 Mich. 643, 250 N.W. 520 (1933) (disorderly persons law forbidding persons of evil reputation to consort together for an unlawful purpose struck down as violating due process by denying defendants the presumption of innocence and shifting the burden of producing evidence to the defendants); Pcople $v$. Belcastro, 356 III. 144, 190 N.E. 301 (1934) (voiding similar vagrancy statute for depriving citizens of liberty without due process and clothing administrative officers with arbitrary and discriminatory powers); People v. Alterie, 356 III. 307, 190 N.E. 305 (1934) (vagrancy statute penalizing evil reputation invalid for denying due process).

11. 210 P.2d 577, rehearing denied, 210 P.2d 577, 586 (Ore. 1949), reversing City of Portland v. Goodwin, No. C-27188, Ore. Circuit Ct., Multnomah County, Feb. 7, 1948 (typewritten). See 63 Harv. L. Rev. 1060 (1950).

12. For summaries of the history of the curfew, which dates back at least to the time of William the Conqueror, see 6 Encyclopedra Britannica 873 (14th ed. 1938); 1 Bouvier's Law Dictionary 738 (8th ed. 1914); Cresswell, The Curfezv: Its Origin and History, 278 GentLeMen's MAGAzINE 599 (1895).

Curfews have rarely been imposed on adults in the United States. The few examples include: (1) a pre-Civil War curfew on Negroes in Montgomery, Ala.-see 2 Lyelt, $A$ Second Visit to the United States of North America 42 (1850); (2) a similar curfew declared unconstitutional when applied to a free Negro in Mayor of Memphis v. Winficld, 8 Humph. 707 (Tenn. 1848); (3) a curfew banning prostitutes from strcets at night "except in instances of reasonable necessity, to be clearly shown by the party charged"upheld in Dunn v. Commonwealth, $105 \mathrm{Ky} .834,49$ S.W. 813 (1899); (4) a curfew in Detroit imposed by the Governor of Michigan following the race riots of June 21, 1943see Rhyne, Municipal Curfew for Minors-Model Ordinance Amnotaled, National INSTITUte of MUNicipal Law OfFicers, Rer. No. 99, p. 2 (1943); (5) a curfew imposed in 1942 on persons of Japanese ancestry living within designated military areas in the Pacific Coast states, upheld under the federal war power in Hirabayashi v. United States, 320 U.S. 81 (1943); Yasui v. United States, 320 U.S. 115 (1943).

Much more common are curfews affecting minors only, enacted in over 3,000 citics and towns. 8 ENCYCLOPEDIA AMERICANA 306 (1948). However, such ordinances are enforced in only about 500 municipalities. Rhyne, op. cit. silpra at 1 . See Note, 79 Sukvey Midmonthly 203 (1943). A curfew for minors was declared unconstitutional in Ex parfe McCarver, 39 Tex. Crim. Rep. 448, 46 S.W. 936 (1898), as an unreasonable restriction on liberty. This ordinance absolutely banned minors from the streets fifteen minutes after the ringing of a 9:00 P.M. curfew bell. But less stringent curfews that permit children to be on the streets at night for certain purposes or under specified conditions have been upheld. People v. Walton, 161 P.2d 498 (Calif. Super. Ct., App. Dep't, Los Angeles County 1945); Baker's Appeal, 22 Pa. Dist. 907, 40 Pa. Co. Ct. 515 (Dauphin County Ct. 1912).

13. Pontzand, Ore Police Code $\$ 16-617$, as amended by Ordinance No. 85199 (Junc 
face ${ }^{14}$ for being so vague as not to define a crime adequately. Apparently disturbed because the ordinance, taken literally, shifts the burden of proof to the defendant and specifies no prohibited act other than presence on the street, ${ }^{15}$ the Oregon Supreme Court in effect interpreted the regulation to make nocturnal presence on the street unlawful only if a person has and $b y$ conduct discloses a purpose to violate $a$ law other than the ordinance. The overt act proscribed, said the court, consists of "going upon the street during the prohibited hours and then and there manifesting by conduct an un-

5, 1947), provides: "Between the hours of $1: 00$ and 5:00 o'clock A.MI., Pacific Standard Time, it shall be unlawful for any person to roam or be upon any street, alley or public place without having or disclosing a lawful purpose."

Before amended, the ordinance read: "It shall be unlawful for any person without having lawful business to roam about the streets or drive about the streets in any vehicle at night after 12 o'clock." This version was declared unconstitutional in City of Portland v. Johnson, No. C-26046, Ore. Circuit Ct, Mfultnomah County, May 29, 1947 (typewritten).

In the briefs, the attorneys for the City of Portland deseribed the original and amended ordinances as "after hours" ordinances, thus trying to avoid the connotation of repression attached to the word "curfew." See Reply Brief for Plaintiff-Appellant, pp. 8, 9, 11, 15, City of Portland v. Goodwin, 210 P.2d 577 (Ore. 1949). On the other hand, the defendants-respondents tried to avoid classification of this ordinance with ragraney laws since the latter have usually been upheld as constitutional. Brief for Defendants-Respondents, pp. 4-6, 41, City of Portland v. Goodwin, 210 P.2d 577 (Ore. 1949). But regardless of the label, the general purposes and effects of vagrancy, curfew or disurderly persons laws are the same, with differences consisting of local variations in test and construetion rather than basic objectives.

14. The Goodwin case reached the Oregon Supreme Court on appeal by the City of Portland from a ruling on a demurrer by the Miultnomah County Circuit Court. Evidence was taken in the Portland Municipal Court, where the defendants were convicted, but not in the Circuit Court. Therefore, there was no record of evidence or bill of exceptions before the Supreme Court, which made its decision independently of the facts of the case. 210 P.2d 577, 579-S0. Several similar vagrancy ordinances have been upheld without regard to the facts. See, e.g., In Re Cutler, 1 Cal.App.2d 273, 36 P.2d 441 (4th Dist. 1934); City of New Orleans v. Postek, 180 La. 1048, 158 So. 553 (1934); Guidoni v. Wheeler, 230 Fed. 93 (9th Cir. 1916).

15. The substance of the evidence offered against the Goodwins was that: "Dciendants offered no logical explanation for their presence on the street." Brief for Plaintiff-Appellant, p. 4, City of Portland v. Goodwin, 210 P.2d 577 (Ore. 1949). No allegation was made that the Goodwins did, or intended to do, anything unlawiul at the time of the arrest. In the Minicipal Court trial, the arresting officer testified that he did not see the defendants do any act in violation of any other law. Communication to the YALE LAW Joursal from David M. Spiegel, attorney for defendants-respondents, dated Dec. 27, 1949, in Yale Law Library. The conviction thus completely disregarded the presumption of innocence. See note 6 supra.

If the ordinance were to prohibit or penalize mere presence on the street, it would violate "freedom of locomotion," which several courts have held to be protected by the Fifth and Fourteenth Amendments. Territory of Hawaii v. Anduha, 31 Hawaii 459 (1930) aff'd, 48 F.2d 171 (9th Cir. 1931) ; Pinkerton v. Verberg, 78 Alich. 573,44 N.W. 579 (1859); Commonwealth v. Doe, 167 Atl. 241 (Pa. Super. Ct. 1933). See note 9 sugro. And see City of St. Louis v. Gloner, 210 Mo. 502, 109 S.W. 30 (1908) (ordinance penalizing loitering held unconstitutional for infringing upon the right of personal liberty and being unreasonable and oppressive). 
lawful purpose." 16 By way of dicta the court expressly said that the ordinance does not allow arrest on mere suspicion, and implied that power to arrest on suspicion could not constitutionally be conferred on the police. ${ }^{17}$

Although saved from complete extinction by the court's construction, the ordinance probably will have little usefulness if the police attempt to apply it as interpreted. The ordinance would now require the police affirmatively to prove a defendant's unlawful purpose. Therefore, if city magistrates scrupulously observe the burden of proof requirements imposed by the court's opinion, police probably will prefer to utilize procedurally more favorable vagrancy statutes to jail suspicious night prowlers. ${ }^{18}$ Moreover, if arrest on suspicion is constitutionally proscribed in Oregon-as the court intimated-arrest under the ordinance can now be made only where the suspect's conduct amounts to an attempt or conspiracy to commit a crime. But if the ordinance covers only attempts or conspiracies, it would usually be superfluous because in these cases arrest could normally be effected under other laws. ${ }^{19}$

16. 210 P.2d 577,586 (Ore. 1949). In its first opinion, the court said, "The overt act consists of placing himself upon a street during the prohibited hours." 210 P.2d 577,581 (Ore. 1949). Not until the opinion denying a rehearing was the ordinance clearly interpreted to require something more than mere street presence for arrest.

17. At 210 P.2d 577, 580, the Oregon court said, "We agree that if the ordinance constitutes authority to arrest merely upon suspicion it would be invalid."

A vagrancy law for the District of Columbia which punished "suspicious persons" was declared unconstitutional in Stoutenburgh v. Frazier, 16 App. D.C. 229 (1900). The court pointed out (id. at 234) that "mere suspicion is no evidence of crime of any particular kind, and it forms no element in the constitution of crime." Sce also Philips v. Leary, 114 App. Div. 871, 100 N.Y. Supp. 200 (2d Dep't 1906). Contra: City of Columbus v. McCrory, 49 N.E.2d 583 (Ohio Ct. of App., 2d Dist. 1942). And see On1o Gen. Code Anv. $\$ 3664$ (Page, 1937) ; Mass. Gen. Laws c. 41, $\$ 98$ (1931), quoted in note 4 supra. Cf. Note, Suspected Persons, 84 J.P. 366 (1920). And see Hopkins, op. cit. supra note 5, passin and especially at 70-71,93 for examples of illegal arrests on suspicion.

The attorneys for the City of Portiand denied that the ordinance authorized arrest on suspicion, saying: "When an officer arrests for the violation of the 'after-hoturs' ordinance he arrests for a violation of that ordinance committed in his presence and the question of arrest for suspicion of commission of a misdemeanor has no application." Reply Brief for Plaintiff-Appellant, pp. 12-13, City of Portland v. Goodwin, 210 P.2d 577 (Ore. 1949). But there seems to be little doubt that suspicion was the motive for arrest of the Goodwins. See note 15, sitpra.

18. One month after the circuit court declared the curfew invalid in the Goodzwin case, the municipal vagrancy ordinance was amended to add the following definitions of a vagrant:

"(c) Any person who habitually roams about from place to place without having any lawful business.

"(e) Any person who wanders about the streets at late or unusual hours of the night without any visible or lawful business." PORTLANd, ORE. Poltce CODE $\$ 16-619$ as amended by Ordinance No. 82313 and No. 86827 (March 4, 1948).

19. Attempts and conspiracies are punishable as common law crimes. MiLLER, $o p$. cit. supra note 9, at 96-105, 107-17. And, at common law, peace officers are authorized to interfere to prevent an attempted felony and arrest the offender without warrant, since an 
Enforcement officials, however, probably will be little affected by the court's abstruse interpretation. The police and even many judges of municipal, magistrate's and police courts are likely to be unaware of the subtle distinctions embodied in the interpretation and to rely upon the apparent literal meaning of the ordinance. 20 Although the appellate courts would be more cognizant of such radical interpretive changes, appeals from convictions under such laws are comparatively rare. 11 Furthermore, in police attempt to commit a felony is normally a breach of the peace. CLakh, op. cit. supra note 2, at 51; VOORHEES, THE LAW OF ARREST $\$ 156$ (2d ed. 1915).

20. Typically, policemen are given little information about the laws they are required to enforce, and they are usually unaware of appellate decisions that affect the meaning of those laws whose texts they may have read. Ifany violations of civil rights by the police are due to ignorance of the law. Cosshall, Are $W_{\mathcal{C}}$ Buying the Trojar Horse?, $40 \mathrm{~J}$. Crmir. L. \& Crrannology 242, 243 (1949); Brereton, Police Training-I/s Necds and Problems, 26 J. Crarr. L. \& Crminnology 247 (1935).

Miagistrates and Justices of the Peace are frequently ignorant of the law they administer. Zimmerman, Justice of the Pcace Courts-Recommendations, 21 ORE L. Rev. 380,381 (1942). They are usually educationally unqualified to do legal research or to apply the technical decisions and statutes they are aware of. Sce generally, Frey, $W c$ Ifust Improve Our Justice of the Pcace Courts, 28 WAsH. U.L.Q. 22, 25 (1942) ; Kross \& Grossman, Magistrates' Courts of the City of New Yorl: Suggested Improtements, 7 Broomeyn L. Rev. 411 (1938); Howard, The Justice of the Pcace Systcm in Temessec, 13 TENN. L. REv, 19 (1934). "Even the settling of a point on appeal does not insure unanimity [in application] thereafter, although copies of opinions on anpeal are cecasionally transmitted to the magistrates by the chief magistrate." Kross \& Grossman, supro, at 423. And see Rep. of the N.J. Civil Liderties Union to the Attonsex-Genersal of the

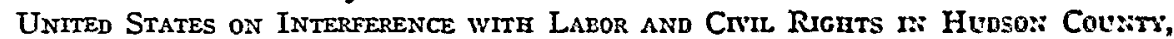
NEW JERSEY (1938) (typewritten), which describes a number of deliberate misapplications of the N.J. Disorderly Persons Act, quoted supra note 4; 4 ReP. of N.r. Cosm'z: 0:: Law Observance and Enforcenient (Wickersham Compr'N), No. 11, Refont 0:: LawlessNESS IN LAW ENFORCEMTENT 319, 324, 326 (1931).

On the other hand, the Municipal Court of Portland has applied the ordinance as construed by the Oregon Supreme Court to at least one case and has discharged the prisoner on that basis. Communication to the Yale LAw Journ.aL from David M. Spiegel, attorney for defendants-respondents, dated Dec. 27, 1949, in the Yale Law Library.

21. For example, out of more than 300 cases decided in the Chicago Vagrancy Court (Crim. Br. No. 1, Mrunic. Ct. of Chicago) from January to June, 1918, only three appeals were perfected. Note, 9 J. Criar. L. \& Crnmology 433, 436 (1918). Only one prer cent of the civil and criminal cases handled by Justices of the Peace are appealed. Spanagel, The Iustice of the Peace System-Siggested Reform, 1939 WIs. L. Rev. 414, 415-6.

Among the factors that militate against appeals from such convictions are:

(a) The poverty of the defendants. The majority of persons prosecuted under curiew, disorderly persons and vagrancy laws are typically the unemployed, the homeless, the poverty-stricken. They rarely can afford to employ attorneys and do not usually arouse enough sympathy to obtain voluntary legal assistance. See Hall, stipro note 5, at 369; Note, 3 Sol. 278 (1936).

(b) The high cost of appeals as compared to the penalty imposed. Sentenees are usually a small fine or a few days in jail, and rarely more than six months. The Goodwins were fined $\$ 25$ each by the Portland Afunicipal Court, but the cost of their agpeals must have been many times that amount. And see Allen, Administralion of Minsor Justice in Selected Illinois Countics, 31 ILL L. Rev. 1047, 1051 (1937).

(c) In some cases the sentence is served before an appeal can be periected. In a 
court trials there is usually no written record for use in reviewing the facts on appeal. ${ }^{22}$ It may therefore prove difficult for the appellate courts to ensure that the ordinance is applied as construed rather than as originally written.

Personal freedom should not be left to the whimsical judgment of police and local courts. ${ }^{23}$ Nevertheless, police need some authority temporarily to detain and investigate suspected persons without arrest or charge-an authority lacking in the traditional law of arrest. The increased use of broadly phrased curfew, vagrancy, and suspicious persons statutes merely reflects the importance of this authority to effective urban law-enforcement. Brief arrests under these vague statutes are often for the purpose of investigations which could otherwise be accomplished only by illegal detention. ${ }^{24}$

But indirection is hardly a satisfactory instrument of public policy. A better solution would be to replace curfew, vagrancy, and suspicious persons laws with a statute that would grant the police detention powers, but subject to specific limits and safeguards. One proposed statute, the Uniform Arrest Act, ${ }^{25}$ would authorize a police officer to stop and question anyone acting in

New Jersey case, bail was set beyond the means of the four defendants after a very doubtful conviction under the Disorderly Persons Act. Ninety-day sentences were served before the New Jersey Supreme Court heard the case and determined that the question had become moot. REP. of THE N.J.C.L.U., op. cit. supra note 20, at 10.

(d) Appeal may not always be available. Convicted defendants are not guarantecd the right to appeal by the United States Constitution, McKane v. Durston, 153 U.S. 684, 687 (1894), or by the constitutions of some of the states. See Millican v. State, 145 Tex. Crim. Rep. 195, 167 S.W.2d 188 (1942); Commonwealth v. Cicere, 286 Pa. 296, 133 Atl. 795 (1926). In Oregon, appeal from a conviction in a municipal court for violating an ordinance may be prohibited by the city charter, except where the ordinance is challenged as unconstitutional. If the right of appeal depends on the existence of such a constitutional issue, the decision of the appellate court can be on the constitutional question only. ORE Comp. LAws ANn. §95-2802 (1947).

22. For example, in Oregon, a justice of the peace is not required by statute "to reduce the testimony of witnesses to writing in criminal trials before him as such justice, and hence the evidence taken in a justice's court on the trial of a criminal action is no part of the record." Tyler v. State, 28 Ore. 238, 240, 42 Pac. 518 (1895). Appeals from convictions in the municipal courts must be taken and perfected in the same manner as appeals from the justice courts. ORE. CoMp. LAws ANN. \$95-2802 (1947).

23. "Freedom from physical restraint at the mere will of another is not liberty." United States ex rel. Howard v. Ragen, 59 F. Supp. 374, 379 (N.D. Ill. 1945). Accord, Yick Wo v. Hopkins, 118 U.S. 356 (1886).

24. See note 5 supra and note 31 infra.

25. The Uniform Arrest Act was prepared by a committee appointed by the Interstate Commission on Crime in 1939, with Prof. Sam Warner as the reporter. The Act is printed in full and discussed in Warner, The Uniform Arrest Act, 28 VA. L. Rev. 315, 343-7 (1942), reprinted in Interstate Commission on Crine, HaNdBook on INTERSTATE CrIme Control 86 (1942). The Act has been adopted with some mollifications in New Hampshire (N.H. Laws 1941, c. 163, N.H. Rev. LAws c. 423, \$21 (1942)) and Rhode Island (R.I. Pub. Laws 1941, c. 982). It has been approved by the International Association of Chiefs of Police. 
a suspicious manner in a public place, provided that no person could be detained for more than two hours. ${ }^{26}$ Detention would not constitute an arrest or be recorded as such. ${ }^{27}$ If sufficient grounds are discovered for charging the detainee with a specific crime, he could then be arrested; otherwise, he would be released without further formalities."s

26. Uniform Arrest Act \$2: "(1) A peace officer may stop any person abroad who he has reasonable ground to suspect is committing, has committed or is about to commit a crime, and may demand of him his name, address, business abroad and whither he is going.

"(2) Any person so questioned who fails to identify himself or explain his actions to the satisfaction of the officer may be detained and further questioned and investigated.

"(3) The total period of detention provided for by this section shall not exceed two hours. The detention is not an arrest and shall not be recorded as such in any official record. At the end of the detention the person so detained shall be released or be arrested and charged with a crime." Warner, stipra note 25 , at 344.

"The two hour limitation prevents temporary detention from being transferred into imprisonment ex communicado without the safeguards of arrest and its conscquent responsibilities." Warner, stpra note 25 , at 322 .

The detention section of the Uniform Arrest Act has not yet been judicially examined, but it should be held constitutional as a reasonable exercise of the police power. In some states the police are authorized to stop and question people on the streets, and such action does not constitute an arrest. Gisske v. Sanders, 9 Cal. App. 13, 98 Pac. 43 (2d Dist. 1908) ; and see People v. Henneman, 367 III. 151, 154, 10 N.E.2d 649, 650 (1937): State v. Zupan, 155 Wash. 80, 90, 283 Pac. 671, 675 (1929). But see Judson v. Reardon, 16 Minn. 431 (1871) (voiding an ordinance providing that any person disobeying orders during a fire may be arrested and detained until the fire is extinguished). Watchmen and constables in England seem to have had the power not only to question but to detain suspicious persons at night. The English authorities are cited and discussed in Miles v. Weston, 60 III. 361, 365-6 (1871) and in Warner, stipra note 25, at 318-19.

27. See UNIFORM ARREST ACT $\$ 2(3)$, quoted in note 26 supra. Although detention is very similar to arrest, using a different label may make a significant practical difierence with respect to humiliation of the innocent detainee, his employment, reputation, etc. Warner, supra note 25 , at 322 .

In most cities, the police, when they are seeking suspeets, are prone to arrest persons who have been arrested before. Frequently, if an arrestee is cleared of the charge no entry to that effect is made in the arrest record. Eventually, through a long record of arrests (and whether or not the disposition of the case is recorded on the arrest record), a person may be tagged as a "known criminal" although he has never been convicted of a serious crime. Once he has acquired that reputation he may subsequently be subjected to prosecution under known criminal and disorderly persons statutes. See, e.g., People v. Pieri, 269 N.Y. 315, 199 N.E. 495 (1936), especially the dissenting opinion; Commonwealth v. Eliis, 207 Mass. 572, 93 N.E. 823 (1911). And see Hopkiss, op. cit. supra note 5, at 116-119.

28. Under the present law in most jurisdictions, an arrested person must not be released by the police, but must be brought before a magistrate. Keefe v. Hart, 213 dlass. 476, 100 N.E. 558 (1913). Contra: Tucker v. Vornbrock, 270 Ky. 712, 110 S.W.2d 659 (1937). Often, the police discover upon investigation that the arrestee is innocent or that there is insufficient evidence to hold him. But the magistrate's court may not be open until the next day, and the arrestee is forced to spend the night in jail. This overnight detention is not only inconvenient and humiliating, but it may cause the arrestee to lose a day's wages or even his job. Warner, supra note 25 , at 336-9.

A police officer who releases an innocent arrestee without bringing him before a magistrate may be held liable for damages for false imprisonment. Hall, supra note 5, 
In its present form, however, the Uniform Arrest Act would not adequately protect the public against arbitrary detention by the police. An ideal statute would embody additional safeguards. The detainee should be guaranteed the right to notify his relatives, friends and counsel of his detention. ${ }^{29}$ He should be informed that he need not reply to questions if the answers would tend to incriminate him. ${ }^{30}$ And there should be no penalty for refusal to cooperate in the investigation.

at 354-63; but see Voorhers, op. cit. supra note 19, \$97. But cf. Peloquin v. Hibner, 231 Wis. 77, 285 N.W. 380 (1939). Nevertheless, great numbers of arrestees are illegally released without being brought before a magistrate. For example, between 1913 and 1919, $67 \%$ of those arrested as disorderly persons in Detroit were discharged by the superintendent of police after being held from a few hours to a few days. Mandel, Analysis of Arrests and Police Court Cases in Detroit, 11 J. Crim. L. \& Crinrnolocy 413, 414 (1920). See Hopkins, op. cit. supra note 5, at 76-87; Hall, supra note 5, at 350-62; UNIronus CRIME Reports, op. cit. sitpra note 1 at 49-51. Cf. UnIform ARrest ACT $\$ 10$ (authorizing release of arrestees by the police).

29. Detention beyond the two hour limit will be less likely to occur after such notification since there will then be third party witnesses to the length of detention who will also be able to apply for a writ of habeas corpus. Much financial loss to the detainee and the anguish of his relatives may be avoided if he is able to notify the persons concerncd of his plight. Furthermore, third degree methods and other abuses are more likely to occur when the victim is detained incommunicado. Hall, stupra note 5, at 357; REP. OF NAT. Comm' $N$, op. cit. supra note 20, at 31 and 210-11 (statistics); Hopkins, op. cit. supra note 5 , at 120 and passim. Refusal by the police to permit notification would be evidence that the detention was illegal in any subsequent civil or criminal action. At present there are a few statutes that penalize refusal to permit an arrestee to communicate with friends or counsel. Nev. Comp. Laws $\$ 10488$ (1929); OHIo Gen. Cone $\$$ 13432-15, 13432-16 (1937); Calif. Penal Code $\$ 825$ (Deering, 1949); and 1935 Colo. Stat. Ann. c. $48, \$ 560$ (1935).

Perhaps as a further precaution, the detention system should be supervised by officials who are independent of the police department. Such officials should have at least the power (1) to inspect any police station or jail at any time, (2) to release any picrson illegally detained, and (3) to file charges against any police officer who has illegally detained anyone or has used illegal methods in questioning anyone.

30. The provisions of the federal and state constitutions protecting the privilege against compulsory self-incrimination are limited to testimonial compulsion under process of some kind directed against the defendant as a witness. 4 WiGNORE, Evidence 835, 879 ( $2 \mathrm{~d}$ ed. 1923). However, as a corollary to the rule against involuntary confessions, many statutes provide that an arrested person must be cautioned about his right to refrain from making incriminating statements at the preliminary hearing or arraignment. FED. RuLEs of Crim. Proc., Rule 5(b), 5 F.R.D. 581 (1946); OHo Gen. Code $\$ 13433-13$ (1937); A.L.I., Code of Crim. Proc. $\$ 47$ (1930). And see Note, Acctuseds' Statements to the Police, 22 N.Z.L.J. 148 (1946); and 71 Sot. J. 610 (1927). In some jurisdictions a confession is admissible in evidence only if voluntarily made after the prisoner has been warned that it may be used against him. Texas Code of Crus. Proc. ANN. art. 727 1925) ; Cross v. State, 142 Tenn. 510, 221 S.W. 489 (1920). But in most states there seems to be no clear recognition by the police of any duty to inform a person held by them of his right to keep silent. See, e.g., Haley v. Ohio, 332 U.S. 596, 604 (1948). Consequently, the detention statute itself should expressly require the police to inform detainecs of their constitutional rights. Any other course would violate the spirit, if not the letter, of the rules against involuntary confessions and self-incrimination. 
With these safeguards, a detention statute would reduce much of the harassment to which innocent persons are often subject under the present law of arrest. The stigma of arrest itself would be removed. The statute would curb the long detentions-legal and illegal-which have almost become an integral part of existing enforcement processes. ${ }^{31}$ And it would eliminate

31. The wide-spread practice of long detentions, ranging from a few hours to several weeks, is reported upon in HopkrNs, op. cit. supra note 5, at 120-\$9 and fossim; and Rep. of NAT. Conrar's, op. cit. supra note 20, at 94-120 and passim. In many states, comparatively long detentions are perfectly legal. For example, CAL. PEx. CODE \$ \$25 1949) requires that an arrestee must be brought before a magistrate "within two days after his arrest, excluding Sundays and holidays." N.H. REv. LAws c. 423, $\$ 30$ (U:iroms ARREST ACr $\$ 11$ ) requires production of the arrestee in court within twenty-four hours, if possible, Sundays and holidays excluded; but a judge may authorize a further delay of forty-eight hours. However, most statutes provide merely that the arrestee shall be brought before a magistrate "forthwith" (Ky. Codes ANn., Crrar. Code of Prictice \$46 (Carroll, 1948)), or "with reasonable promptness" (CoNN. GEN. Stat. \$465 (1949)), or "without unnecessary delay" (ARTz. CODE ANN. \$\$ 44-107, 44-140 (1939)), or "without any intermediate incarceration" (DeL. Rev. CoDE $\$ 5173$ (1935)). (The citations to the state statutes are collected in $\mathrm{M} 1 \mathrm{cNabb}$ v. United States, 318 U.S. 332, 342-3, n.7 (1943).) These phrases are usually interpreted to mean a reasonable time according to the facts of the case. Janus v. United States ex rel. Humphrey, 38 F.2d 431, 437 (9th Cir. 1930). The results have varied widely. Thus a delay of an hour and a half between arrest and arraignment has been held unreasonable. Keefe v. Hart, 213 Mass. 476, 100 N.E. 558 (1913). But "police departments throughout the country almost unanimously avail themselves of approximately 48 hours before bringing a man before a magistrate. . ." REP. of Nat. Consar's, op. cit. supra note 20, at 211 . This procedure is considered legal by some police chiefs and courts in spite of the statutes. HopkINs, op. cit. stipra note 5, at 159. A two day detention for questioning, without any charge being made, has been held reasonable as a matter of law. Peloquin v. Hibner, 231 Wis. 77, 285 N.W. 380 (1939). And see note 28 supra.

A few states have made it a misdemeanor to willfully delay in taling a prisoner before a magistrate. ARIz. CODE ANn. \$43-3908 (1939); CAr. PEN. CODE $\$ 145$ (1949); IDAmo Code $\$ 18-702$ (1948); and Mont. Rev. Codes $\$ 94-3916$ (1947). But it is questionable whether the average prosecutor, who usually works closely with the police and is sometimes a party to the detention (c.g., Peloquin v. Hibner, 231 Wis. 77, $285 \mathrm{~N}$.W. 380 (1939)), would be willing to take action except in the most flagrant cases.

One of the severest blows against the practice of illegal detention was strucl: by the Supreme Court when it held that any confession obtained during an illegal detention was inadmissible in a federal court. McNabb v. United States, 318 U.S. 332 (1943); Anderson v. United States, 318 U.S. 350 (1943). Nevertheless, similar, cases arose repeatedly in the federal courts (e.g., Akowskey v. United States, 158 F.2d 649 (D.C. Cir. 1946)), and the Supreme Court was forced to reiterate its position in Upshaw v. United States, 335 U.S. 410 (1948) (arrest on "suspicion"). Although similar decisions had been reached by some state courts (e.g., State v. Condit, 307 MFo. 393, 270 S.W. 286 (1925)), the MeNabb rule is not binding on the states. Many state courts have rejected it in favor of a rule admitting any confession not coerced by violence, hope or fear even if the coniession occurred as a result of an illegal detention. In the year following the $T /$ shore case, the $M c N a b b$ rule was approved in no reported state appellate decisions and was rejected in: Ingram v. State, 42 So.2d 30 (Ala. Ct. of App. 1949), aff'd 42 So.2d 36 (Ala. 1949); James v. State, 65 A.2d \&88 (MId. 1949); Walker v. State, 205 P.2d 335 (Ohila Crim. Ct. of App. 1949) (arrest for "investigation"); Williams v. State, 205 P.2d 524 (Ol:la. Crim. Ct. of App. 1949); and State v. Klausner, 4 N.J. Super. 427,67 A.2d $46 S$ (1949). 
the present practice of prosecuting innocent persons under vagrancy-type statutes merely to foreclose suits for false arrest. ${ }^{32}$ At the same time, a detention statute would meet the legitimate needs of law enforcement. Two hours would usually be sufficient for the police to determine whether there is reasonable cause to arrest the detainee for the commission of a crime. ${ }^{\text {ab }}$

There are of course dangers inherent in any detention statute. Police may abuse the authority granted them by intimidating the cletainee and by violating such civil rights as freedom of speech and assembly. ${ }^{34}$ They may

But another line of recent Supreme Court decisions has greatly narrowed the admissibility of confessions in the state courts under the Fourteenth Amendment. The Court las: reversed convictions based on confessions obtained without physical torture when the dcfendants were illegally detained for several days, during which time the police interrogated them persistently, failed to inform them of their constitutional rights, and denied them the aid and presence of friends, relatives and counsel. These cases, however, did not turn on the unlawful detention alone, but on the combination of the above factors-a combination which amounted to psychological coercion which rendered the confessions obtained thereby as involuntary as those obtained through physical violence. Watts v. Indiana, 338 U.S. 49 (1949) ; Turner v. Pennsylvania, 338 U.S. 62 (1949); Harris v. South Carolina, 338 U.S. 68 (1949) ; Haley v. Ohio, 332 U.S. 596 (1948); Malinski v. New York, 324 U.S. 401 (1945). (In a concurring opinion, Justice Douglas urged that any confession obtaincd during an illegal detention should be outlawed on that ground alone as a denial of due process. Watts v. Indiana, 338 U.S. 49, 57 (1949).)

32. These laws are, in fact, so drawn as to facilitate a conviction in order to protect the police even though the defendant has not done anything detrimental to society. See Kooken, supra note 5, at 74, 179-80; REP. OF THE N.J.C.L.U., op. cit. supra note 20, at 43; and Rep. of NAT. CoMm'N, op. cit. supra note 20, at 108-9. If a very short detention for investigation were allowed, such prosecutions would probably decline sharply even if the vagrancy and disorderly persons statutes were not repealed. Cf. Hopkiss, op. cit. supra note 5, at 87.

Convictions may also be had to protect private party complainants. In one case, the then Chief of Police of Jersey City was reported to have said that if the defendants were acquitted it would cost the Central R.R. of N.J. one million dollars in false arrest suits. The defendants were convicted and given suspended sentences. REP. OF THE N.J.C.L.U., op. cit. supra note 20 , at 31 .

In a false arrest or malicious prosecution suit, if the plaintiff was convicted of the offense for which he was arrested, it is conclusive evidence of reasonable cause for arrest. E.g., Turbessi v. Oliver Iron Mining Co., 250 Mich. 110, 229 N.W. 454 (1930).

33. With modern criminal identification methods and rapid means of communication and transportation at its command, an efficient police force should be able to establish accurately, through use of fingerprints, photographs and witnesses, the detaince's identity, residence and past criminal record in the community within two hours. In many cases, a detainee's alibi and recent movements can be checked within that period, too. If additional time is needed for the investigation, the suspect can be released with comparative assurance that he will not attempt to escape from the jurisdiction since flight would be exceedingly dangerous once the police have an accurate description of him and have him under surveillance. And frequently, reasonable grounds for arrest can be established long before the investigation is completed or conclusive evidence of guilt obtained. The limited length of detention may quicken the pace of detective work, but it is not likcly to impair the effectiveness of the police.

34. A two hour detention period is long enough to disrupt a picket line, to prevent a speaker from addressing a meeting, to "deport" an "undesirable" (sce Comment, The Hague Injutction Proceedings, 48 Y ALE L.J. 257, 261-2 (1938)), or to obtain information 
also disregard the statutory time limit for detention. These abuses have been common under existing arrest laws, ${ }^{35}$ and the present remedy-a suit for false arrest or imprisonment against the police-is in most cases more theoretical than real. Many victims of police abuse are too poor to sue or are unaware that they can. And even if a plaintiff wins, most policemen are judgment-proof or nearly so, and liability on bonds, where bonds are required, is so hedged with technicalities and exceptions as to afford little or no protection. ${ }^{36}$

As companion to a detention statute, therefore, a more effective remedy for abuse should be supplied. The most promising remedy lies in a statute making the municipality employing the policeman absolutely liable for all torts he commits in carrying out his duties-torts such as false arrests, detentions beyond the time limit specified in the detention statute, and detentions for shorter periods without reasonable grounds. $\$ 7$ The remedy

by violent third-degree methods. See Hopkins, op. cit. supra note 5, passim; REP. of NAT. Conns' $N$, op. cit. supra note 20 , passim.

35. These laws have frequently been employed to persecute labor organizers, strikers, members of unpopular political minorities and others. During the labor disputes in the Imperial Valley in 1933, an employee of the International Labor Defense was arrested for "roam[ing] about from place to place without any lawful business" (CAL. PEs. COEz $\$ 647(3)$ (1949)) when she drove into Imperial Valley to obtain legal assistance for some of the hundreds of farm strikers arrested on similar charges. The main evidence against her was the claim that she and her employer were conneeted with the Communist Party. She was convicted and sentenced to six months in jail. The conviction was affirmed without opinion by the Superior Court of Imperial Valley on $\mathrm{A}$ [ay 15, 1934. 3 INT'L JURID. Ass'v BuLL. No. 8, p. 4 (1935). The statute was upheld in a subsequent habeas corpus proceeding. In re Cutler, 1 Cal. App. 2d 273, 36 P.2d 441 (4th Dist. 1934).

Four union organizers who came to Jersey City to address a meeting of workers involved in a strike were convicted under N.J. Laws 1934 c. 133 \$ (similar to Disorderly" Persons Act, N.J. Stat. ANn. $\$ 2: 202-16$ (1939); see note 4 supra). The arresting officer testified that they had told him their purpose, but that he did not consider it a lawiful purpose. 2 INT'L JURm. Ass'N BULL. No. 5, p. 3 (1933) ; REP. of TIE. N.J.C.L.U., op. cit. supra note 20 , at 12 .

Under a St. Louis ordinance making it unlawful to associate with persons reputed to be thieves, prostitutes, and the like, a man was convicted on no more evidence than that he happened to reside in a neighborhood infested with such people. The conviction was reversed in City of St. Louis v. Fitz, $53 \mathrm{M}$ o. 582 (1873). Cf. Pcople v. Pieri, 269 N.Y. 315, 199 N.E. 495 (1936). But even when the defendant is acquitted, or is released upon filing an appeal because of certainty of reversal (see REP. OF N.J.C.L.U., op. cit. supro note 20, at $1,3,12)$, or his conviction is reversed on appeal, the cost to him in time lost from work, expenses of defense, damage to reputation, etc., is very great. Furthermore, the immediate aim of the police in breaking a strike, preventing a meeting or intimidating a citizen will often be accomplished. See, generally, for scores of cases documenting such abuses, REP. of N.J.C.L.U., op. cit. supra note 20, passim; 2 InT'L JuRd. Ass's BuLL. No. 6, p. 2 (1933) ; 3 INT'L JuRd. Ass'N BuLL No. 10, p. 2 (1935); 5 INT'L Jurid. Ass': Bul.. No. 5, p. 54 (1936); Hopkins, op. cit. supra note 5, passim. And see Kookes, supra note 5, at $179-80$.

36. Some of the worst abuses have been classified by the courts as colore officii acts for which the sureties cannot be held liable. Hall, sipra note 5, at 346-53.

37. Municipalities are not liable for the torts of the policemen they employ unless a 
against the city should be exclusive: the injured person should have no right of action against the officer. ${ }^{38}$ In case an officer flagrantly violates regulations, the municipality should have an action over against him. But when he acts in good faith the city alone should bear the cost of compensation. This cost should be borne by the community for whose protection the tortious actions were taken rather than by the policeman who is acting sincerely or by the innocent victims of the enforcement process. ${ }^{39}$ The mere passage of such a statute would not directly ameliorate the lot of the victim who is too poor or too ignorant to make us of it. But with the chances of cash recovery materially enhanced, legal assistance would be more readily available-perhaps earnestly offered-on a contingent-fee basis.

By replacing existing arrest-on-suspicion laws with a detention statute and a municipal tort claims act, individual liberty is not ideally protected nor are the powers of law enforcement as great as police may think necessary. But a fair compromise between these two objectives would be achieved, with a large measure of protection for the individual, the police and the community.

statute specifically imposes such liability. 6 MCQuilim, Municipal CorPoratrons $\S 2591$ (2d ed. 1928).

Administrative as well as purely judicial remedies might be provided, at least in the case of small claims. Fedrral Tort Claims Act, 28 U.S.C. $\$ 2671$ (Supp. 1950), would be an excellent model except for the unfortunate inclusion of 28 U.S.C. $\$ 2680$ (h) (Supp. 1950), which exempts claims arising out of false imprisonment, false arrest and malicious prosecution. An administrative determination, however, might prove extremely unfair to the claimants. Unlike most judges, municipal officials administering the tort claims law may be subjected to heavy pressure to cut down the size and number of the awards. And again, the claims of the ignorant and the destitute are the ones most likely to be sacrificcd in order to save city funds and conceal the extent of polce abuse.

38. A great number of policemen are sued for false arrest at some time in their careers, and although a judgment is rarely recovered and executed against them, the cost of the defense is often disastrous to them. If the officers acted under the orders of supcriors ar in good faith, such suits might seriously damage police morale and effectiveness. Seo Warner, Investigating the Law of Arrest, 26 A.B.A.J. 151, 155 (1940). Cf. FedERAL Totr Claiars ACr, 28 U.S.C. $\$ 2672$ (Supp. 1950).

39. Tort liability is not likely to impose a serious financial strain on the municipalities. See Warp, The Law and Administration of Municipal Tort Liability, 28 VA. L. Rev. 360, $376-9$ (1942). In the long run, municipal liability may prove to be the cheaper policy since a policeman who has been sued for false arrest is likely to be more cautious in the future, perhaps to the point of failing to provide adequate protection.

The principal advantage to be gained from false arrest suits is the cumulative effect they have in deterring police abuse. Comment, The Hagne Injunction Procecdings, 48 YALE L.J. 257, 262 n. 30 (1938). This effect would probably register more rapidly if all the suits had to be defended by the city, rather than the individual policemen, and the municipal authorities had to face the prospect of explaining the suits and the expenses incurred to the voters at the next election. This might prove especially valuable as a deterrent in those cities where lawless enforcement of the law is the official policy of the municipal government. See Hopkins, op. cit. supra note 5, at 49-51, 183. 